\title{
ANALISIS SISTEM PENGGAJIAN DALAM UPAYA PENGENDALIAN INTERNAL PERUSAHAAN
}

\author{
Oleh: Padriyansyah ${ }^{1}$, Trie Sartika Pratiwi ${ }^{2}$ \\ padriyansyah@univ-tridinanti.ac.id ${ }^{1}$, \\ 1 (Program Studi Akuntansi, Fakultas Ekonomi , Universitas Tridinanti Palembang) \\ ${ }^{2}$ (Program Studi Akuntansi, Fakultas Ekonomi, Universitas Sriwijaya)
}

\begin{abstract}
Abstrak-Penelitian ini bertujuan untuk menganalisis sistem penggajian sebagai upaya dalam pengendalian internal perusahaan pada PT. Salsabila Perkasa. Jenis data yang digunakan peneliti data primer yaitu data non-numerik seperti hasil wawancara mengenai sistem informasi akuntansi penggajian dan pengupahan serta sistem pengendalian internal yang dijalankan perusahaan PT. Putra Salsabila Perkasa. Teknik analisis yang digunakan dalam penelitian ini adalah analisis deskriptif yaitu menganalisa dan mendekripsikan serta membandingkan data yang diperoleh. Hasilnya menunjukkan sistem informasi akuntansi penggajian di PT. Putra Salsabila Perkasa belum mendukung upaya pengendalian internal karena masih kurangnya dalam struktur organisasi pemisahan tugas tersendiri untuk sistem penggajian yang dapat menyebabkan peluang terjadinya kecurangan dalam penggajian.
\end{abstract}

Kata Kunci : Sistem Penggajian, Pengendalian Internal

\begin{abstract}
This study aims to analyze the payroll system as an effort in the company's internal control at PT. Mighty Salsabila. The type of data used by primary data researchers is non-numeric data such as the results of interviews regarding the payroll and wage accounting information system and the internal control system run by the company PT. Son of the Mighty Salsabila. The analytical technique used in this research is descriptive analysis, namely analyzing and describing and comparing the data obtained. The results show the payroll accounting information system at PT. Putra Salsabila Perkasa has not supported internal control efforts because there is still a lack in the organizational structure of separate segregation of duties for the payroll system which can lead to opportunities for fraud in payroll.
\end{abstract}

Keywords: Payroll System, Internal Control

\section{PENDAHULUAN}

Sumber daya manusia merupakan salah satu pilar penyangga utama perusahaan untuk menggerakkan roda suatu organisasi dalam mewujudkan visi dan misi perusahaan, salah satu cara agar tujuan perusahaan tersebut dapat tercapai, perusahaan membutuhkan sebuah sistem informasi akuntansi dalam menunjang perusahaan dapat berjalan dengan baik.

Sistem informasi akuntansi adalah organisasi formulir, catatan, dan laporan yang dikoordinasikan sedemikian rupa untuk menyediakan informasi keuangan yang dibutuhkan oleh manajemen guna 
memudahkan pengelolaan perusahaan (Mulyadi 2016). Menurut Krismiaji (2015), sebuah sistem berfungsi memproses data dan transaksi yang berguna untuk menghasilkan informasi yang bermanfaat untuk merencanakan, mengendalian, dan mengoperasikan bisnis untuk dapat menghasilkan informasi yang diperlukan oleh para pembuat keputusan.

Untuk itu, sumber daya manusia perlu dikelola dengan baik serta menggunakan cara yang profesional. Sebagai imbalan kepada sumber daya tersebut, maka perusahaan memberikan serangkaian penghargaan dimana salah satu komponennya adalah gaji. Gaji ialah pembayaran atas pemberian jasa yang telah dilakukan dam diberikan oleh karyawan yang memiliki jenjang jabatan manajer, sedangkan upah ialah pembayaran atas pemberian jasa yang telah dilaksanakan oleh karyawan pelaksana. Sistem akuntansi penggajian dan pengupahan ialah sistem yang dipakai oleh perusahaan untuk memberikan upah dan gaji kepada para karyawan atas pemberian jasa yang mereka berikan (Sujarweni, 2015).

Jika sistem informasi akuntansi di sebuah perusahaan tidak baik maka akan menimbulkan suatu gejala yang merugikan, misalnya terjadi pembayaran gaji yang fiktif atau pengalokasian biaya yang tidak sesuai. Oleh karena itu pada perusahaan terdapat permasalahan yang terjadi pada PT. Putra Salsabila terletak pada sistem pembayaran gaji dimana ketika pembayaran gaji karyawan yang dibayarkan secara rutin setiap bulannya tidak ditanda tangani oleh karyawan yang menerima gaji sehingga tidak adanya bukti penerimaan gaji. Persamalahan lain yang juga terjadi pada PT. Putra Salsabila Perkasa yaitu di mana bagian pencatatan waktu hadir juga melakukan pembuatan daftar gaji. Hal ini dikhawatirkan dapat menimbulkan terjadinya penyelewengan jam kerja, manipulasi data dan kesalahan dalam pencatatan sistem penggajian.

Masalah lain juga terdapat pada proses absensi di mana tidak adanya pengawasan khusus dari bagian yang terkait. Sering perhitungan yang tidak sesuai misalnya ketika karyawan datang telat atau tidak masuk, atau pulang sebelum waktunya. Sehingga ketidakakuratan hasil perhitungan gaji karyawan yang mengakibatkan kesalahan pencatatan waktu kerja karyawan karena sistem pencatatan waktu absensi yang masih manual.

Pemanfaatan sistem pengendalian internal dapat dilakukan untuk mencegah penyelewengan perusahaan. Pengendalian internal ialah elemen dari sistem yang mencakup struktur organisasi, cara, dan ukuran yang dipadukan guna menjaga kekayaan organisasi, memeriksa keandalan dan ketelitian dari data akuntansi, mendorong kemampuan dan mendorong peraturan manajemen dipatuhi (Mulyadi, 2013).

Menurut Tantoli (2017) dalam Langi dkk (2019),Penerapan dan pelaksanaan pengendalian internal menjadi hal yang penting dalam menentukan potensi kesalahan dan 
ketidakberesan serta dampak yang akan terjadi pada laporan keuangan. Sistem pengendalian intern merupakan proses pemantauan yang memungkinkan manajemen mengetahui apakah tindakan yang dilakukan dan bagaimanakah tindakan koreksinya jika pelaksanaan tidak sesuai dengan yang telah ditetapkan semula (Fionita \& Magdalena, 2015).

Salah satu upaya dalam meningkatkan pengendalian intern perusahaan yaitu dengan adanya sistem akuntansi penggajian yang baik. Hubungan sistem akuntansi penggajian dengan pengendalian intern sangatlah terkait satu sama lain, karena suatu bagian akan terkontrol oleh bagian lain melalui laporan yang sampai kepada pihak manajemen, serta dengan adanya pengendalian intern akan terjaganya kekayaan milik perusahaan dengan baik dan keakuratan data akuntansi dapat terkendali guna dijadikan informasi bagi manajemen dalam mengelola perusahaannya, sehingga pembayaran gaji dapat berjalan sebagaimana mestinya sesuai dengan prosedur yang sudah ada, serta sistem akuntansi yang baik nantinya akan dapat menghasilkan sistem pengendalian intern perusahaan yang efektif (Saraswati, 2014), (Fibriyanti, 2017).

Berdasarkan latar belakang diatas maka dirumuskan sebuah perumusan masalah yaitu ;’Bagaimana sistem penggajian sebagai upaya dalam pengendalian internal perusahaan pada PT. Salsabila Perkasa ?’. Sedangkan tujuan dari penelitian ini yaitu untuk menganalisis sistem penggajian sebagai upaya dalam pengendalian internal perusahaan pada PT. Salsabila Perkasa.

\section{METODE PENELITIAN \\ Ruang Lingkup Penelitan}

Ruang lingkup penelitian ini adalah untuk melakukan analisis sistem penggajian dalam upaya pengendalian internal perusahaan pada PT. Putra Salsabila Perkasa.

1) Lokasi dan Waktu

Lokasi penelitian adalah PT. Putra Salsabila Perkasa yang beralamat di Jalan Ratu Alamsyah Prawiranegara Ruko No.03 Rt.10 Rw.02 Gandus Palembang.

2) Batasan Penelitian

Berdasarkan identifikasi masalah di atas, maka peneliti membatasi ruang lingkup masalah penelitian ini yaitu sistem penggajian dalam upaya pengendalian internal perusahaan pada PT. Putra Salsabila Perkasa.

\section{Jenis dan Sumber Data}

Untuk melengkapi penelitian secara akurat maka peneliti harus memiliki data. Data digunakan sebagai media atau bahan untuk menyusun suatu penelitian. Jenis dan sumber data yang digunakan dalam penelitian ini adalah kualitatif.

1. Menurut Sugiyono (2019) metode penelitian kualitatif adalah metode penelitian yang berlandaskan pada filsafat postpositivisme, digunakan untuk meneliti pada kondisi obyek yang alamiah, (sebagai lawannya adalah eksperimen) dimana peneliti 
adalah sebagai instrument kunci, teknik pengumpulan data dilakukan secara trianggulasi (gabungan), analisis data bersifat induktif/kualitatif, dan hasil penelitian kualitatif lebih menekankan makna dari generalisasi. Data yang digunakan peneliti adalah data non-numerik seperti hasil wawancara mengenai sistem informasi akuntansi penggajian dan pengupahan serta sistem pengendalian internal yang dijalankan perusahaan PT. Putra Salsabila Perkasa.

2. Sumber data yang digunakan dalam penelitian ini adalah data data primer berupa data-data dalam proses sistem akuntansi penggajian dan pengupahan serta sistem pengendalian internal yang digunakan perusahaan. Menurut Sugiyono (2019:194) data primer adalah sumber data yang langsung memberikan data kepada pengumpul data. Sumber data yang digunakan dalam penelitian ini adalah data primer yang di diperoleh PT. Putra Salsabila.

\section{Teknik Pengumpulan Data}

Teknik pengumpulan data primer yang diperoleh adalah secara langsung melalui wawancara terhadap pimpinan perusahaan, manajer keuangan, manajer personalia, manajer akuntansi dan staf yang terkait dengan pengelolaan gaji dan upah pada PT. Putra Salsabila Perkasa untuk mengetahui sistem akuntansi penggajian dan pengupahan serta pengendalian internal yang dilakukan perusahaan

\section{Teknik Analisis Data}

Teknik analisis data yang digunakan dalam penelitian ini adalah analisis deskriptif yaitu menganalisa dan mendekripsikan serta membandingkan data yang diperoleh dari PT. Putra Salsabila Perkasa dengan teori yang dipakai sehingga dapat memberikan informasi dan dapat ditarik kesimpulan.

\section{HASIL DAN PEMBAHASAN}

Bagan Alir Sistem Penggajian dan Standar Operasional Prosedur PT. Putra Salsabila

Bagan alir sistem penggajian karyawan pada PT. Putra Salsabila Perkasa.

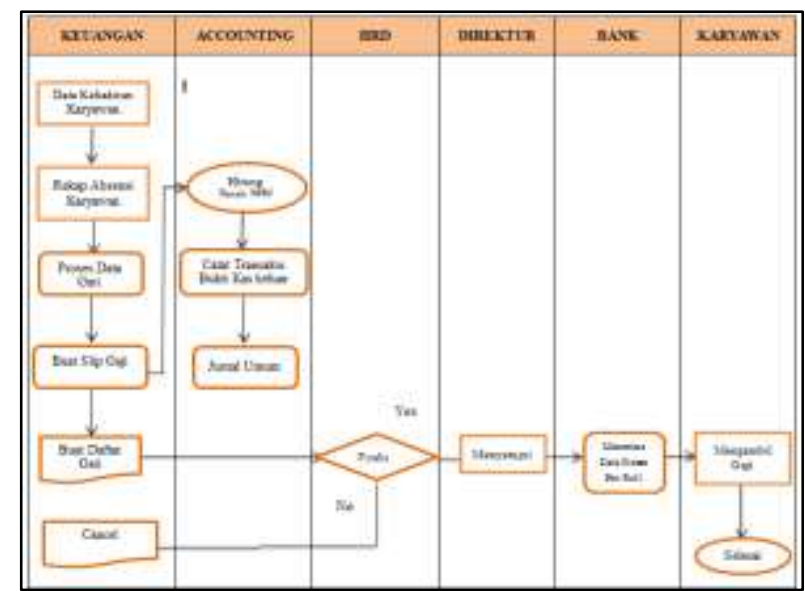

Gambar 1. Alir Sistem Penggajian PT. Putra Salsabila Perkasa Palembang (Sumber: PT. Putra Salsabila Perkasa) 
Adapun SOP (Standar Operasional Procedur) dalam PT. Putra Salsabila Perkasa adalah :

1. Absensi karyawan dilakukan dipagi hari pada saat sebelum jam kerja dimulai, yaitu jam 07.00 WIB. Karyawan mencatatkan kehadirannya dalam daftar hadir. Bagian keuangan merekap absensi karyawan PT. Putra Salsabila Perkasa Palembang.

2. Bagian keuangan merekap absensi karyawan PT. Putra Salsabila Perkasa Palembang.

3. Bagian keuangan menyerahkan rekap absensi karyawan kepada bagian HRD untuk di evaluasi dan kroscek ulang.

4. Bagian keuangan mengecek dan menghitung hasil rekapitulasi absensi karyawan untuk menghitung total penerimaan gaji karyawan.

5. Bagian keuangan menghitung gaji karyawan dan membuat slip gaji karyawan, kemudian menandatangani total gaji karyawan.

6. Bagian keuangan menyerahkan slip gaji ke bagian accounting untuk mencatat transaksi dan menghitung PPh Pasal 21 dan mencatat bukti kas keluar.

7. Bagian keuangan menyerahkan total gaji karyawan kepada bagian HRD.

8. Bagian HRD mengevaluasi dan mengecek hasil total perhitungan gaji yang dibuat oleh bagian keuangan kalau sudah benar akan ditandatangani oleh manajer kemudian akan diserahkan ke direktur.

9. Direktur menyetujui hasil rekapitulasi dan menandatangi rekapitulasi gaji karyawan.

10. Direktur menyerahkan Giro ke bagian keuangan untuk dicairkan di bank dan melakukan pembayaran gaji.

11. Bagian keuangan mencairkan Giro ke Bank.

12. Selanjutnya bagian keuangan menyerahkan gaji kepada karyawan.

\section{Fungsi Yang Terkait Dalam Sistem Penggajian}

Fungsi yang terkait dalam siklus penggajian pada PT. Putra Salsaila Perkasa Palembnag adalah :

1. Fungsi Personalia

Fungsi ini berada dibawah bagian direktur PT. Putra Salsabila Perkasa yang dijalankan oleh bagian HRD (Human Resource Development) dan mempunyai tanggung jawab sebagai berikut :

a. Melakukan persiapan dan seleksi tenaga kerja.

b. Menjadi penghubung antar manajemen dengan karyawan.

c. Mengawasi proses perekrutan, wawancara kerja, seleksi, dan penempatan karyawan baru.

2. Fungsi Akuntansi

Fungsi ini berada dan dijalankan bagian staff pembukuan dan mempunyai tanggung jawab untuk mencatat transaksi pembayaran gaji karyawan seperti hutang gaji dan hutang pajak. 
3. Fungsi Keuangan

Fungsi ini berada dan dijalankan bagian staff keuangan. Bertanggung jawab untuk mengisi cek pembayaran gaji dan upah dan mencairkan cek tersebut ke bank. Dalam menjalankan fungsi keuangan, staff keuangan juga bertanggung jawab atas catatan waktu hadir bagi semua karyawan dan melakukan rekapitulasi kehadiran karyawan setiap bulan dan diberikan pada bagian akuntansi.

\section{Dokumen Yang Digunakan Sistem Penggajian}

Dokumen-dokumen

yng

digunakan dalam sistem informasi penggajian pada PT. Putra Salsabila Perkasa adalah :

1. Daftar hadir

Dokumen ini berisi waktu hadir karyawan yang digunakan untuk mencatat kehadiran karyawan. Dokumen hasil catatan absensi manual yang digunakan oleh PT. Putra Salsabila Perkasa Palembang dalam absen jam kerja dan jam pulang. Dokumen ini menjadi salah satu acuan bagian keuangan untuk merekap dan menyusun daftar gaji karyawan.

2. Daftar gaji karyawan

Dokumen ini berisi jumlah gaji setiap pegawai yang ditambah tunjangan-tunjangan dan dikurangi potongan-potongan, iuran-iuaran dan lain-lain.

3. Rekap daftar gaji karyawan
Rekap daftar gaji karyawan merupakan ringkasan gaji yang dibuat selama satu bulan.

\section{Slip Gaji}

Slip gaji merupakan dokumen ini dibuat sebagai catatan bagi setiap karyawan mengenai rincian gaji dan upah yang diterima setiap karyawan beserta berbagai potongan yang menjadi beban setiap karyawan.

5. Amplop gaji karyawan

Amplop gaji yang digunakan yang masih sederhana, yang berisi nama. Uang gaji dimasukkan ke dalam amplop kemudian diserahkan kepada nama karyawan yang bersangkutan setiap bulannya.

6. Bukti Kas Keluar

Dokumen ini berisi perintah pengeluaran uang yang didasarkan atas informasi atas informasi dari daftar gaji.

\section{Catatan Akuntansi Yang Digunakan Sistem Penggajian}

Catatan akuntansi yang digunakan pada pelaksanaan penggajian pada PT. Putra Salsabila Perkasa adalah sebagai Jurnal umum. Jurnal umum digunakan untuk mencatat biaya gaji. Dokumen sumber untuk melakukan pencatatan ke dalam jurnal ini adalah slip gaji karyawan.

\section{Jaringan Prosedur Pencatatan Sistem Penggajian}

Prosedur yang membentuk sistem penggajian yang ada dalam PT. Putra Salsabila Perkasa, (1) pencatatan waktu hadir karyawan, dimulai dengan 
melakukan pencatatan waktu ketika datang dan pulang kerja. Didalam PT. Putra Salsabila Perkasa fungsi pencatat waktu ada ditangan bagian keuangan selanjutnya melakukan prosedur pencatatan waku hadir hingga menghitung rekapitulasi waktu hadir karyawan hingga prosedur pembuatan daftar gaji karyawan sesuai dengan data yang telah di rekapitulasi dalam satu bulan. (2) pembuatan daftar gaji, yang yang dikerjakan oleh bagian gaji setelah menghitung hasil rekapitulasi yang telah di verifikasi oleh bagian keuangan untuk menghitung total penerimaan gaji karyawan, kemudian (3) pembayaran gaji, bagian keuangan menyerahkan total gaji karyawan kepada bagian akuntansi. Bagian akuntansi mengevaluasi dan mengecek hasil total perhitungan gaji yang dibuat oleh bagian keuangan dan menjadi sumber bagi pembukuan perusahaan. Cek Gaji yag telah diterbitkan harus memerlukan persetujuan dari direksi sebelum diteruskan ke bagian keuangan untuk melakukan pembayaran gaji.

\section{Analisis Fungsi Yang Terkait Dalam Sistem Penggajian}

Di dalam fungsi yang terkait dalam sistem penggajian pada PT. Putra Salsabila Perkasa ini sudah cukup baik tetapi masih ada kelemahan karena terlihat jelas bahwa belum adanya pemisahan tugas dalam fungsi pencatat waktu tidak terpisah tersendiri, dan dalam dalam penelitian ini peneliti menemukan adanya penumpukan tugas dalam satu fungsi yaitu antara fungsi pencatat waktu dan fungsi keuangan.

\section{Analisis Dokumen Yang Digunakan Sistem Penggajian}

Dalam dokumen yang digunakan sistem penggajian PT. Putra Salsabila Perkasa sudah cukup baik, namun masih menggunakan dokumen-dokumen penggajian daftar hadir yang masih manual, daftar gaji yang direkap masih perhitungan manual. Hal ini membutuhkan waktu dalam pemrosesan penggajian karena masih perhitungan gaji yang masih manual.

\section{Analisis Catatan Akuntansi Yang Digunakan Sistem Penggajian}

Catatan akuntansi yang diguanakan dalm sistem penggajian pada PT. Putra Salsabila Perkasa sudah baik. Hal ini terlihat dari perusahaan yang sudah melakukan pencatatan pembukuan transaksi yang berhubungan dengan penggajian dengan dibuatkannya jurnal umum.

\section{Analisis Jaringan Prosedur Yang Membentuk Sistem Penggajian}

Pada PT. Putra Salsabila Perkasa prosedur penggajian yang digunakan sudah baik, dimulai dari pencatat daftar hadir, pembuat daftar gaji, prosedur bukti kas keluar, sampai prosedur pembayaran gaji. Kelebihan dalam penggajian pada PT. Putra Salsabila Perkasa Palembang ini didalam penggajian direktur terlibat langsung, dimana cek gaji harus ada persetujuan dari direktur. Namun kelemahannya 
adalah terdapat penumpukan tugas dimana fungsi ini menjalankan prosedur pencatatan waktu dan prosedur keuangan, hal ini dapat menyebabkan tindakan kecurangan.

Hal ini sejalan dengan penelitian Langi, dkk (2019) pada PT. Gemilang Emas Indonesia yang menghasilkan analisis bahwa sistem akuntansi penggajian belum sepenunhnya mendukung dalam upaya pengendalian internal. Hal ini dapat dilihat dari masih adanya kekurangan dalam pemisahan dan pembagian tugas dalam struktur organisasi dan praktik yang sehat. Serta Aprilliadi (2019) pada PT Semen Indonesia Packing Plant Ciwandan belum sesuai Sistem informasi akuntansi penggajian dan pengupahan dengan teori yang dikemukakan oleh Mulyadi karena terjadi perangkapan tugas yang dilakukan bagian pencatatan waktu hadir dengan pembuat daftar gaji serta bagian akuntansi dengan keuangan.

\section{KESIMPULAN}

Berdasarkan hasil analisa penulis yang telah diuraikan diatas mengenai sistem penggajian di PT. Putra Salsabila Perkasa, maka dapat disimpulkan sistem akuntansi penggajian karyawan pada PT. Putra Salsabila Perkasa belum mendukung dalam upaya pengendalian internal perusahaan. Hal ini dikarenakan struktur organisasi yang tidak ada pemisahan tugas tersendiri untuk sistem penggajian seperti tidak ada bagian pencatat waktu hadir karyawan, dan rekap absensi karyawan yang dapat menyebabkan peluang terjadinya kecurangan dalam penggajian.

\section{DAFTAR PUSTAKA}

Aprilliadi, Teddy. (2019). Analisis sistem informasi akuntansi penggajian dan pengupahan dalam upaya pengendalian internal pada karyawan outsorcing. Pendekar: Jurnal Pendidikan Berkarakter Vol. 2, No. 1, Hal. 01-07

Fibriyanti, Y. V. (2017). Analisis Sistem Informasi Akuntansi Penggajian dalam Rangka Efektivitas Pengendalian Internal. Jurnal Akuntansi, Volume 2 Nomor (1), 14.

Fionita, I., \& Magdalena, B. (2015). Penerapan Sistem Informasi Manajemen Pada Usaha Kecil Menengah Di Provinsi Lampung. Jurnal Bisnis Darmajaya, Volume 1, Nomor(2), 98-107

Krismiaji, (2015). Sistem Informasi Akuntansi, Edisi keempat, Sekolah Tinggi Ilmu Manajemen YKPN, Yogyakarta

Langi, Branda, David P. E. Saerang dan Natalia Y. T. Gerungai (2019). Analisis Sistem Informasi Akuntansi Penggajian Dan Pengupahan Dalam Upaya Pengendalian Internal Pada Pt. Gemilang Emas Indonesia. Jurnal Riset Akuntansi Going Concern Volume 14 Nomor (1), 148-153

Mulyadi. (2016). Sistem Akuntansi. Edisi Ketiga. Salemba Empat. Jakarta.

Saraswati, K. (2014). Analisis Sistem Akuntansi Penggajian \& Pengupahan Karyawan Dalam Usaha Meningkatkan Pengendalian Intern Perusahaan (Studi pada PT. Japfa Comfeed Indonesia, Tbk Kantor Cabang 
Sidoarjo). Jurnal Administrasi Bisnis S1 Universitas Brawijaya, Volume 8, Nomor (1).

Sugiono. (2019). Metode Penelitian Kuantitatif, Kualitatif, dan $R \& D$. Bandung: Alfabeta.

Sujarweni, V. Wiratna. (2015). Sistem Akuntansi. Pustaka Baru Press. Yogyakarta 